\title{
Opsoclonus Myoclonus Syndrome
}

National Cancer Institute

\section{Source}

National Cancer Institute. Opsoclonus Myoclonus Syndrome. NCI Thesaurus. Code C4686.

A combination of opsoclonus (involuntary conjug ate eye movements of large amplitude) and myoclonic jerks. This can be a paraneoplastic syndrome (a result of brain metastasis) or post-infectious (viral encephalitis). 